The object of the Frederick Soddy Trust is to develop the study of the social, economic and cultural life of specific geographical regions on the general lines developed by the Le Play Society (see Nature, 191, 1144 ; 1961). Mr. B. T. Wood, formerly assistant lecturer in geography in the University College of Wales, Aberystwyth, has been appointed the first Soddy Research Fellow.

\section{Industrial Support for School Science in Britain}

IN the latter part of 1955 an appeal was launched to British industry for a fund to improve the facilities for teaching the physical sciences in those schools which could not look for support to the Ministry of Education or the Local Education Authorities. A sum of more than $£ 3,000,000$ was raised and by 1957 most of the resources had been allocated and building operations were well under way. The grants for building thus provided enabled the number of rooms for teaching physies and chemistry to be increased by nearly 50 per cent. By 1959 most, if not all, of the buildings were in full operation, and in 1960 the funds then seen to be available enabled grants to be made to ten schools not previously helped. All schools receiving building grants also received help toward the purchase of apparatus, and in addition, other schools not receiving building grants were given help to purchase apparatus; altogether, 326 schools were helped. In July 1962, grants were made to twelve schools taking part in a 'pilot scheme' for teaching physics on more modern lines, to enable them to purchase the necessary special apparatus, and a grant was made to the Science Masters' Association to assist in the setting up of their headquarters at Cambridge. A sum has also been set aside for the issue of a brochure on the design and equipment of science buildings to be published shortly. During the winding-up operation, the secretary will be Sir Graham Savage (Barbary, Maresfield Park, Near Uckfield, Sussex), to whom correspondence should now be addressed. All the funds at the disposal of the Executive Committee of the Fund have been committed and no further requests can now be entertained.

\section{National Nature Week}

THE Council for Nature is sponsoring a National Nature Week in order to direct the attention of the public to the pleasure that can be obtained from studying Britain's wildlife and to the need for active conservation. It is hoped that the majority of the 300 member bodies of the Council will arrange special events during the week and that every sizeable town will have a programme of local events, including competitions for school children, film shows, popular lectures and exhibitions. Such activities will be arranged by local natural history societies and county naturalists' trusts. Many museums are arranging exhibitions, often with the collaboration of local naturalists, and it is expected that most public libraries will organize displays of natural history books. Openair activities will play a large part in the week: guided rambles and tours, labelled nature trails and visits to nature reserves, including some of those under the Nature Conservancy, are being planned. The Council itself is holding a competition for natural history photographs and arranging exhibitions in London and Edinburgh on Britain's wildlife intended to attract large numbers of the general public. Further information can be obtained from the General Secretary, Council of Nature, 41 Queen's Gate, London, s.W.7.

\section{Analytical Methods for Meteorites}

AN invitation conference on analytical methods for meteorites was held at the British Museum (Natural History) during September 5-6. Of the twenty participants, ten came from overseas; a communication on analytical methods used in the U.S.S.R. was received. The four sessions of the conference were devoted to: determination of the principal constituents of 'irons' (iron, nickel, cobalt, sulphur and phosphorus), and the separation of the metal, sulphide and silicate parts of stones; determination of the principal constituents of stones, with especial reference to the determination of $\mathrm{Al}_{2} \mathrm{O}_{3}, \mathrm{CaO}, \mathrm{Na}_{2} \mathrm{O}$ and $\mathrm{K}_{2} \mathrm{O}$; determination of trace elements in irons and in stones; and the use of the Castaing microanalyser. The selection and preparation of material for analysis were also discussed. A report on the conference is available from the Department of Mineralogy, British Museum (Natural History), Cromwell Road, London, S.W.7.

\section{Peaceful Uses of Nuclear Power}

Atom, No. 70, August 1962, includes, besides papers by Dr. R. Roberts on uses of nuclear radiation in the textile industry, and by F. R. Farmer on the evaluation of power reactor sites, Sir Roger Makins's speech to the British Nuclear Energy Society on May 30, in which he suggested that 1962 would inaugurate a third period in the peaceful application of nuclear energy: the years of fresh advance. He attributed present disillusionment about nuclear power to overoptimistic economic forecasts and to underestimates of the technical problems involved in bringing civil nuclear power stations into being. It seemed likely that by the early 1970's nuclear stations would be generating power on base load as cheaply as the best coal-fired stations situated near to the East Midlands or Yorkshire coalfields, and when towards the end of the century the cheaper known uranium deposits might begin to run out, nuclear energy would be at a stage which would permit the mining of uranium from plentiful but higher-cost low-grade deposits. Sir Roger recognized that there were political as well as economic considerations to be taken into account, but he was satisfied that the structure of the industry and the relations of the Authority with industry and the Government was appropriate. He briefly reviewed the reactor systems which the Authority was developing or assessing, noting the importance of the use of pre-stressed concrete pressure vessels for the magnox system and the potentialities of the steam generating heavy-water reactor and the work at Culham on the fusion of the lighter elements.

\section{Cultural Problems in Pictorial Perception}

Prctorral perception depends on artistic convention; unacculturated groups do not comprehend this convention and misperceive the cues. Tests of perception of pictorial depth carried out by Dr. W. Hudson on European, coloured Bantu and Indian samples gave that descending order of three-dimensional pictorial perception with educated samples (South African Journal of Science, 58, No. 7; July 1962). Evidence from school-going Bantu groups and from European and Bantu occupational samples warranted the hypothesis that cultural experience and not educational standard was the determining factor in dimensional perception of picture material. Misperceptions of symbolism in the Western style picture were reported. The need for further research 